\title{
Histological and hormonal studies of calabash chalk on ovarian function in adult female wistar rats
}

\author{
OYEWOPO, A. O. * OBASI, K. K., ANUMUDU, K. and YAWSON E. O. \\ Department of Anatomy, University of Ilorin, P.M.B. 1515, Postal Code 23401, Ilorin, Kwara State, Nigeria \\ *E-mail: obasikosisochukwu@yahoo.co.uk.
}

\begin{abstract}
Introduction: Calabash chalk is a naturally occurring mineral, chiefly composed of fossilized sea shells. It is prepared from clay and mud mixed with other ingredients, including lead, arsenic, sand and wood ash. Clay consumption is correlated with pregnancy, and also to eliminate morning sickness in women. The aim of this study is to evaluate the effects of calabash chalk on the ovarian function in adult female Wistar rats. Methods: Eighteen (18) adult female Wistar rats. Group A served as the control group, group B received $40 \mathrm{mg} / \mathrm{kg}$ body weight of Non-salted calabash chalk while group C received $40 \mathrm{mg} / \mathrm{kg}$ body weight of Salted calabash chalk for 14 days. On day 15 , the animals were sacrificed for histological and biochemical examination. Results: Results showed a significant $(\mathrm{P}<0.05)$ reduction in follicle stimulating hormone $(\mathrm{FSH})$ levels of the treatment groups when compared with the control group and an increase in luteinizing hormone (LH) levels of the treatment groups when compared with the control group. Histological examination of the ovaries showed severe deterioration of the ovarian follicles, necrosis and follicular atresia. Conclusion: Calabash chalk is toxic to ovarian function. These alterations have been shown to be the leading cause of infertility in female rats. Hence, proper monitoring, education, and regulation of the product is needed.
\end{abstract}

Keywords: salted calabash chalk, non-salted calabash chalk, follicle stimulating hormone, ovaries.

\section{Introduction}

In Nigeria communities, calabash chalk is traditionally consumed as a remedy to morning sickness, nausea and for pleasure. It is reported to be consumed mostly by breastfeeding, non-pregnant and pregnant even though it's not a conventional food (MAPHERSON and PINCUS, 2007). Calabash chalk is used as an antiperspirant and facial powder when grounded (POPOOLA, BISI-JOHNSON, ABIODUN et al., 2013). It is also known as calabar stones, Nzu by the Igbos, Ndom by the Efiks/Ibibios of Nigeri, Mabele by the Lingala of Congo, Argile or La Craie in French (DEAN, DEARY, GBEFA et al., 2004). Calabash chalk is made up of aluminium silicate hydroxide $\left(\mathrm{Al}_{2} \mathrm{Si}_{2} \mathrm{O}_{5} \mathrm{OH}_{4}\right)$, a member of the kaolin clay group. It consists of metalloids and metals like lead; which forms a high percentage of its constituent, arsenic, iron, aluminium, potassium, zinc, titanium, manganese, barium, chromium, copper, nickel, rubidium and tin respectively (CAMPBELL, 2002).

The quantity of lead is reported to be approximately $40 \mathrm{mg} / \mathrm{kg}$ while organic pollutants like alpha lindane, endrin and endosulphan are found in the chalk (OLUWOLE and BOLARINWA, 1998). Geophagia can be defined as the habitual and intentional ingestion of chalks, clays and soils (HALSTED, 1968). Calabash chalk comes in two main forms either as a crude rock sourced directly from the ground or as a mixture that is compacted and fired into a solid.

Two types of chalk exists, they are; Salted and Non-salted calabash chalk exists. Although there is paucity of researches in this area, reports have shown that it causes fragmented liver parenchyma and hepatic sinusoidal enlargements (EKONG, AKPANTAH, IBOK et al., 2009; EKONG, PETER, AKPANABIATU et al., 2013), depletion of red blood cells (AKPANTAH, IBOK, EKONG et al., 2010), splenomegaly
(EKONG, EKANEM, ABRAHAM et al., 2009), oedema with haemorrhages in the mucosa of the stomach, hyperkeratosis, acanthosis, and koilocytic changes in the mucosa of the oesophagus (EKONG, JOHN, MBADUGHA et al., 2012), as well as growth rate alteration and femur bone demineralization (EKONG, EKANEM, SUNDAY et al., 2012).

Constituents of calabash chalk like Kaolin, has been implicated microgliosis, reactive astrocytosis, inflammation, and brain damage (DEREN, PACKER, FORSYTH et al., 2010; KHAN, ENNO and DEL BIGIO, 2006) while lead causes pregnancy problems, as well as, behavioural and deficits in young children (CANFIELD, HENDERSON JUNIOR, CORY-SLECHTA et al., 2003; SHANNON, 2003).

It's also known to induce biochemical, physiological and behavioural dysfunctions in the central and peripheral nervous systems in human and animals (BRESSLER, KIM, CHAKRABORTI et al., 1999; GOYER, 1996). Arsenic, a constituent of the chalk could damage tissues and organ systems including the skin, nervous, cardiovascular, respiratory, and gastrointestinal tract (FRUMKIN and THUN, 2001).

Therefore, these reports on calabash chalk and/or its constituents on different tissue and organ systems show a disturbing trend that can affect ovarian function leading to infertility. Thus, this study is to evaluate the effects of the chalk on ovarian function in adult female Wistar rats.

\section{Ethical Approval}

The experimental protocol was by the University ethical review committee, University of Ilorin, Ilorin, Nigeria. The research was approved to be in compliance with the institutional animal care and Use committee (IACUC). 


\section{Materials and Methods}

A total of eighteen (18) adult female Wistar rats weighing between $180 \mathrm{~g}$ and $280 \mathrm{~g}$ were procured and bred in the animal house of the Department of Anatomy, University of Ilorin. They were raised at normal room temperature and were given feeds and water ad libitum. The Wistar rats were subjected to a period of two weeks of acclimatization before treatment. The body weights of the rats were taken weekly using the high precision Electronic Analytical Weighing Balance in the Department of Anatomy, University of Ilorin.

All rats were assessed, screened and confirmed to ascertain their health status during the acclimatization period. The two forms of calabash chalk (Salted and Non-Salted) were purchased as blocks from Oja Oba, local market in Ilorin, Kwara State, Nigeria.

\subsection{Animal grouping}

The animals were randomly divided into three (3) groups of six (6) rats in each group.

Group A- received $1 \mathrm{ml}$ of distilled water per day.

Group B- received $40 \mathrm{mg} / \mathrm{kg}$ body weight of Non-salted calabash chalk daily.

Group C- received $40 \mathrm{mg} / \mathrm{kg}$ body weight of Salted calabash chalk daily.

All animals were sacrificed 24 hours after the last day of the exposure (which lasted for 14 days) through abdominopelvic incision by anaesthetizing the animals with $0.2 \mathrm{ml}$ of ketamine.

\subsection{Preparation and administration of extract}

The two forms of chalks (Figure 1) were grinded into powder and $\mathrm{lg}$ of each powder was dissolved in $100 \mathrm{ml}$ of distilled water. Then, $40 \mathrm{mg} / \mathrm{kg}$ body weight equivalent of the chalk solution was administered to the experimental animals using an oral cannula.
The formula for the solution was prepared by using:

Volume of $\mathrm{X}(\mathrm{ml})=$ weight of rat $(\mathrm{kg}) \times$ dosage $(\mathrm{mg} / \mathrm{ml})$ Concentration of $\mathrm{X}(\mathrm{mg} / \mathrm{ml})$

\subsection{Hormonal analysis}

For luteinizing and follicle stimulating hormone analyses, the rats of Groups A - C were dissected in the antero-median plane to expose the thoracic region immediately after euthanasia. Blood samples for hormonal assays were obtained from the heart through cardiac puncture with the aid of a $5 \mathrm{ml}$ syringe from all rats employed in the study. The serum was separated by centrifugation at $3000 \mathrm{rpm}$ for 15 minutes. Follicle stimulating hormone and Luteinizing hormone levels were determined based on the principles described in Assay kits of Randox Laboratories (United Kingdom).

\subsection{Evaluations luteinizing hormone (LH) levels}

Microplate wells were formatted for each serum reference, control and specimen to be assayed in duplicate. $0.05 \mathrm{ml}(50 \mu \mathrm{\mu l})$ of the appropriate serum reference, control or specimen was pipetted into assigned well. $0.1 \mathrm{ml}(100 \mu \mathrm{l})$ of LH-Enzyme Reagent was added to all wells. The microplate was swirled gently for 20-30 seconds for proper mixing. The plate was incubated at room temperature for 60 minutes. The content of the microplate was discarded by decantation (using absorbent paper to blot the plate dry). $350 \mu \mathrm{l}$ of was buffer was added and decanted. The procedure was done thrice for proper washing of microplate. $0.100 \mathrm{ml}(100 \mu \mathrm{l})$ of working substrate was added to all wells. The reagents were added in the same order to minimize reaction time differences between wells. The plate was incubated at room temperature for 15 minutes. $0.005 \mathrm{ml}(50 \mu \mathrm{l})$ of stop solution was added to each and was mixed for 15-20 seconds. Each absorbent was read at $450 \mathrm{~nm}$ in a microplate reader (using a well reference wavelength of 620-630 nm to minimize well imperfection).

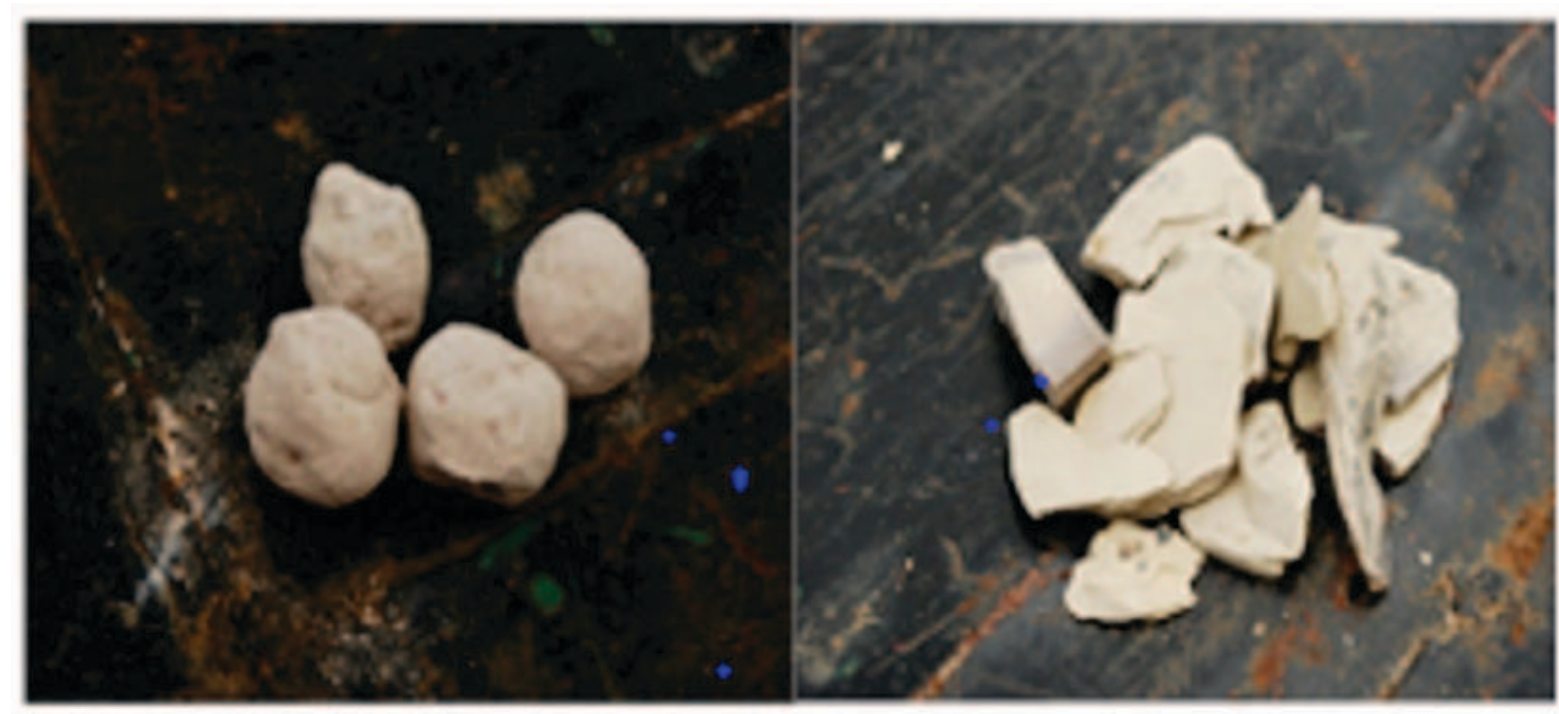

(a)

(b)

Figure 1. Diagram showing (a) salted calabash chalk and (b) non-salted calabash chalk (Campbell, 2002). 


\subsection{Evaluations of follicle stimulating bormone (FSH) levels}

The Microwell follicle stimulating hormone (FSH) EIA is a solid-phase enzyme immunoassay based on the 'sandwich' principle. Two separate antibodies directed against distinct antigenic determinants of the FSH molecule were utilized in the assay. The FSH present in the test sample reacted simultaneously with one antibody immobilized on the microwell surface and with another antibody conjugated to horseradish peroxidase enzyme forming an Ab-Ag Ab Enzyme complex on the microwell surface.

The unbound conjugate was removed by washing while colour development reagents (substrates) were added leading to a colour change upon exposure. Colour intensity was a reflection of the amount of bound anti-FSH enzyme conjugate and it was proportional to the concentration of $\mathrm{FSH}$ in the specimen within the dynamic range of the assay. After reaction stopped, colour measurement was done using a spectrophotometer at $450 \mathrm{~nm}$.

\subsection{Histological analysis of the ovaries}

The ovaries of all the rats were fixed in 10\% formalsaline, dehydrated stepwise in graded ethanol, cleared in xylene and then embedded in paraffin wax. A section of $5 \mu \mathrm{m}$ thick paraffin section of each testicular tissue was stained with hematoxylin and eosin ( $\mathrm{H}$ and $\mathrm{E})$, followed by examination under a light microscope at $\times 100$ magnification and micrographs taken (BANCROFT and STEVENS, 1996).

\subsection{Statistical analysis}

Data from all the groups were statistically analysed using Student's t-test with the aid of SPSS (V20, USA) followed by subsequent analysis by GraphPad Prism v5.01 (GraphPad Software Inc. USA) with statistical significance set at $\mathrm{P}<0.05$.

\section{Results}

\subsection{Physical observation and weight changes in animals}

The total weights of the rats in group $\mathrm{C}$ that received $40 \mathrm{mg} / \mathrm{kg}$ body weight per day of Salted calabash chalk gained weight at the start of treatment but progressively lost weight during the treatment period while the rats in group $\mathrm{B}$ that received $40 \mathrm{mg} / \mathrm{kg}$ body weight of Non-salted calabash chalk per day experienced severe weight loss during treatment while the control group A was on a progressively weight gain.

\subsection{Hormonal analysis}

Results showed there was no significant difference $(\mathrm{P}>0.05)$ in follicle stimulating hormone (FSH) levels for all groups even though a reduction was observed (Figure 2). Significant increase $(\mathrm{P}<0.05)$ in luteinizing hormone $(\mathrm{LH})$ levels was observed for the group that received $40 \mathrm{mg} / \mathrm{kg}$ body weight of Non-Salted Calabash Chalk compared to the control group and the group C that received Salted Calabash Chalk (Figure 3).

\subsection{Histological observation}

Group (A) Showed a normal cytoarchitecture of the ovaries (Figure 4a), (B) Showed the presence of an ovarian follicle atresia (Figure 4b), while group (C) showed the presence follicular atresia, vacuolation and finally necrosis compared to the control group (Figure 4c).

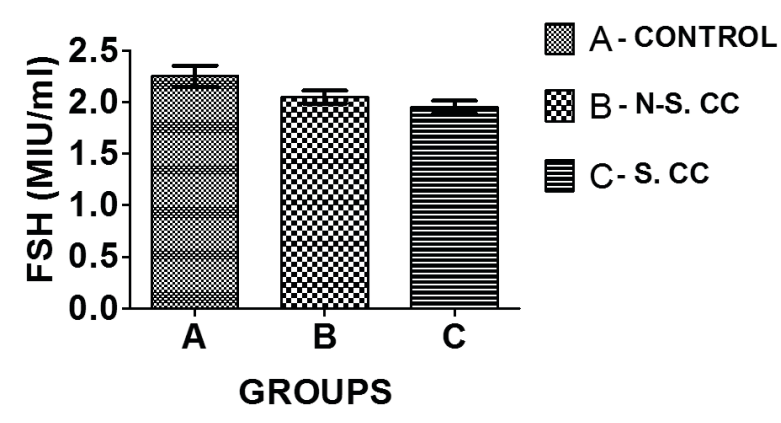

Figure 2. Showing the changes in the follicle stimulating hormone (FSH) levels between treatment and control groups.

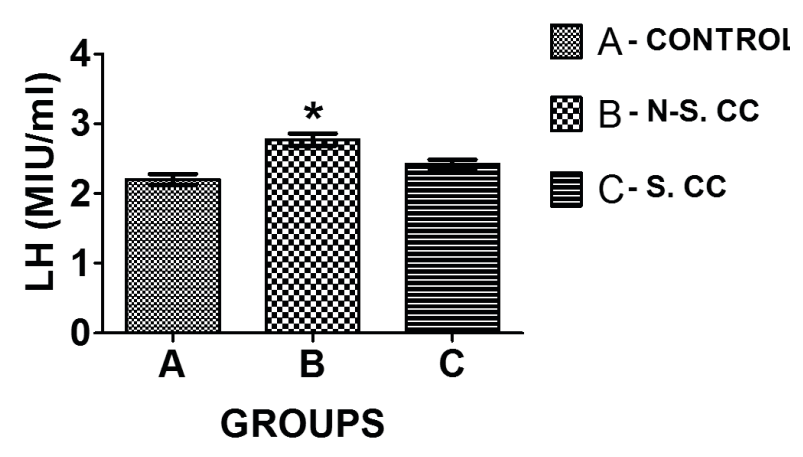

Figure 3. Showing the changes in the luteinizing hormone (LH) levels between treatment and control groups. ${ }^{*}=$ level of significance in $\mathrm{P}<0.05$.

\section{Discussion}

Calabash chalk has been reported to contain several adverse effects known to be detrimental to health. Pregnant and non-pregnant women have a predilection for consuming it especially in Nigeria and other sub-Saharan African countries (DEAN, DEARY, GBEFA et al., 2004). Thus, this study evaluated the effects calabash chalks (Salted and Non-salted) on ovarian function in adult female Wistar rats.

The weight loss observed might be due to the complication of the act of geophagy called "geophagic syndrome" which is marked by growth retardation, delayed sexual maturity, and liver and spleen enlargements (YAO, 2006).

This decrease observed in the levels of FSH and increase in LH could be as a result of disruption of the hypothalamic pituitary-gonadal axis due to its exposure to lead acetate, a constituent of calabash chalk. The impact of this must have been responsible for the arrest of oogenesis in the ovaries pointing to the disrupted ovaries as shown in the histology (DUMITRESCU, CRISTINA and MUSELIN, 2014)

The histological observation of the group administered non-salted calabash chalk were in agreement with reports by authors on the effects of lead, a constituent of calabash chalk strongly suggesting that high levels of lead were linked to altered reproductive function (SILBERSTEIN, SAPHIER, PAZ-TAL et al., 2006; TAUPEAU, POUPON, NOMÉ et al., 2001) and Ovarian atresia, as a result of chronic exposure to lead in female adult rats was reported by (DHIR and DHAND , 2010) and corroborated findings by other authors (TAUPEAU, POUPON, NOMÉ et al., 2001; QURESHI, 

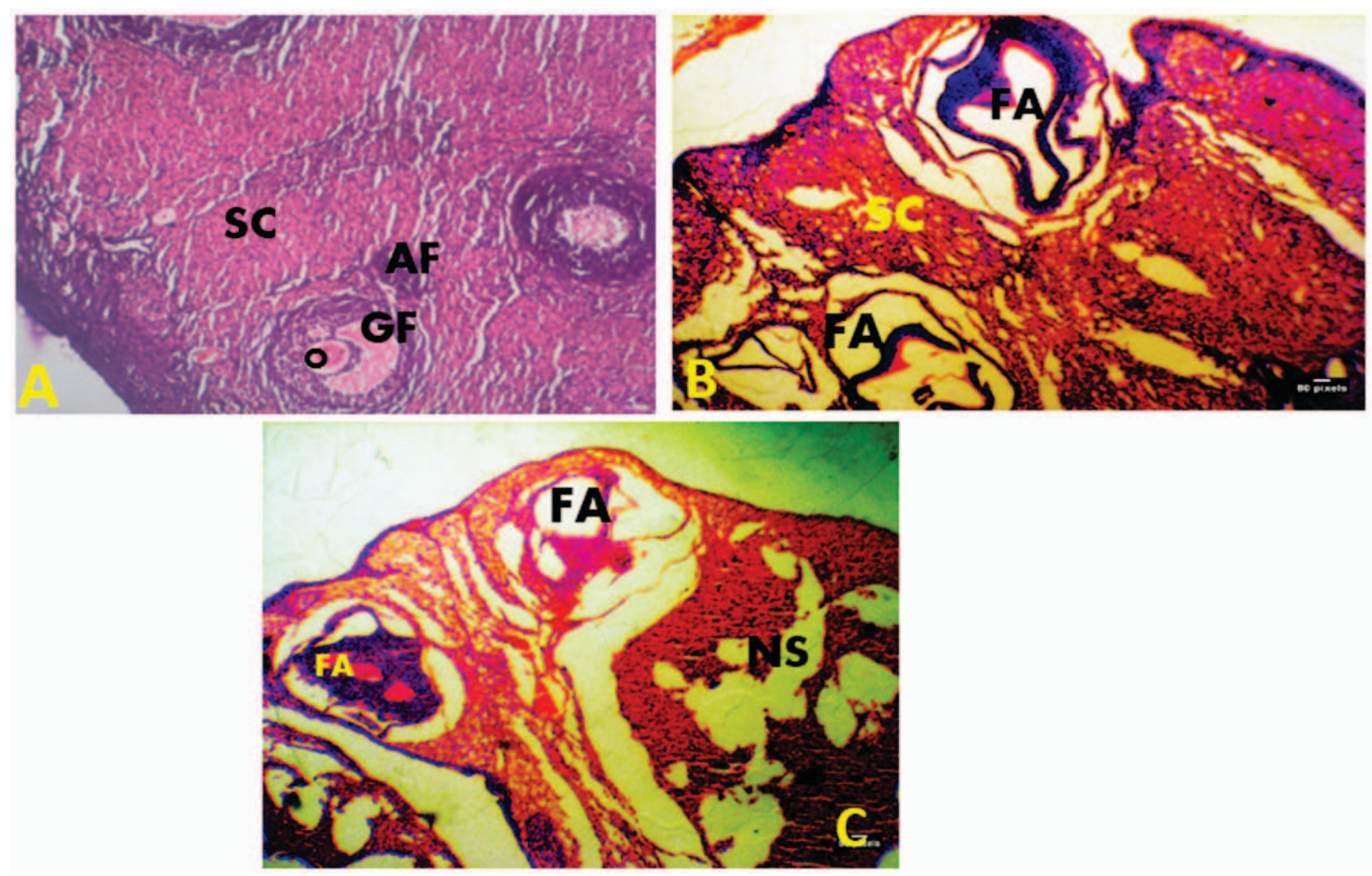

Figure 4. Photomicrograph representative showing the cross-section of the ovaries of Wistar rats in the control group (A), group (B) treated with non-salted calabash chalk, group (C) treated with salted calabash chalk. GF- Graafian follicle, SC-Stroma cells, O- Oocyte, AF- Atretic follicle, FA- Follicular atresia. Stain: Haematoxylin and Eosin. Magnification: $\times 100$.

SHARMA, MOGRA et al., 2010; SHARMA, QURESHI, MOGRA et al., 2012).

The severe deterioration of the ovarian follicles, follicular atresia, presence of vacuolation and finally necrosis observed in group $\mathrm{C}$ might be as a result of high levels of lead exposure, a constituent of salted calabash chalk leading to structural changes in the ovaries indicating infertility in the female rats (DUMITRESCU, CHIURCIU, MUSELIN et al., 2015). This also corroborated with (SHAH, SHARIF, KHAN et al., 2008 ) who reported a reduction in the numbers of ovarian follicles thereby, increasing the number of atretic follicles after oral administration of high doses of lead. All these can be attributed to the effects of lead on reproductive systems which are sex specific and complex, and they seem to involve the hypothalamic-pituitary-gonadal axis on multiple locations, confirming our findings on adult female rats.

\section{Conclusion}

In conclusion, these alterations can disrupt the hypothalamic pituitary-gonadal axis and may have been responsible for the arrest of oogenesis in the ovaries of experimental animals which can be responsible for female factor infertility. Hence, there is need for the proper monitoring, education, and regulation of the product.

Acknowledgements: I would like to acknowledge the Obasi K.K and Anumudu K.I for their technical assistance. This project was not funded by any public, private or corporate institution.

\section{References}

AKPANTAH, AO., IBOK, OS., EKONG, MB., ELUWA, MA. and EKANEM, TB. The effect of calabash chalk on some hematological parameters in female adult Wistar rats. Turkish journal of haematology: official journal of Turkish Society of Haematology, 2010, vol. 27, n. 3, p. 177-181.

BANCROFT, JD. and STEVENS, A. Theory and practice of histological techniques. 4th ed. London: Churchill Livingstone Medical Division of Professional Limited, 1996. 136 p.

BRESSLER, J., KIM, KA., CHAKRABORTI, T. and GOLDSTEIN, G. Molecular mechanisms of lead neurotoxicity. Neurochemical Research, 1999, vol. 24, n. 4, p. 595-600. PMid:10227691. http:// dx.doi.org/10.1023/A:1022596115897.

CAMPBELL, H. Calabash chalk (Calabar stone, La Craie, Argile, Nzu, Mabele). Belfast: Chief Medical Officer, 2002. 4 p.

CANFIELD, RL., HENDERSON JUNIOR, CR., CORY-SLECHTA, DA., COX, C., JUSKO, TA. and LANPHEAR, BP. Intellectual impairment in children with blood lead concentrations below $10 \mu \mathrm{g}$ per deciliter. The New England Journal of Medicine, 2003, vol. 348, n. 16, p. 1517-1526.

DEAN, JR., DEARY, ME., GBEFA, BK. and SCOTT, WC. Characterization and analysis of persistent organic pollutants and major, minor and trace elements in Calabash chalk. Chemosphere, 2004 , vol. 57 , p. $21-25$.

DEREN, KE., PACKER, M., FORSYTH, J., MILASH, B., ABDULLAH, OM., HSU, EW. and MCALLISTER II, JP. Reactive astrocytosis, microgliosis and inflammation in rats with neonatal hydrocephalus. 
Experimental Neurology, 2010, vol. 226, n. 1, p. 110-119. PMid:20713048. http://dx.doi.org/10.1016/j.expneurol.2010.08.010.

DHIR, V. and DHAND, P. Toxicological approach in chronic exposure to lead on reproductive functions in female rats (Rattus norvegicus). Toxicology International, 2010, vol. 17, n. 1, p. 1-7. PMid:21042465. http://dx.doi.org/10.4103/0971-6580.68340.

DUMITRESCU, E., CHIURCIU, V., MUSELIN, F., POPESCU, R., BREZOVAN, D. and CRISTINA, RT. Effects of long-term exposure of female rats to low levels of lead: ovary and uterus histological architecture changes. Turkish Journal of Biology, 2015, vol. 39, p. 284-289. http://dx.doi.org/10.3906/biy-1407-6.

DUMITRESCU, E., CRISTINA, RT. and MUSELIN, F. Reproductive biology study of dynamics of female sexual hormones: a 12-month exposure to lead acetate rat model. Turkish Journal of Biology, 2014, vol. 38 , p. 581-585.

EKONG, MB., AKPANTAH, AO., IBOK, OS., ELUWA, MA. and EKANEM, TB. Differentia effect of calabash chalk on the histology of the liver of adult Wistar rats. The Internet Journal of Health, 2009, vol. 8, n. 2 .

EKONG, MB., EKANEM, TB., ABRAHAM, KE., AKPANABIATU, MI., PETER, AI. and EDEGHA, IA. Effects of calabash chalk on hematology indices and histomorphology of the spleen of growing Wistar rats. Instasci Journal of Medical Sciences and Clinical Research, 2009, vol. 2, n. 1, p. 1-7.

EKONG, MB., EKANEM, TB., SUNDAY, AO., AQUAISUA, AN. and AKPANABIATU, MI. Evaluation of calabash chalk effect on femur bone morphometry and mineralization in young wistar rats: a pilot study. International Journal of Applied \& Basic Medical Research, 2012, vol. 2, n. 2, p. 107-110. PMid:23776822. http:// dx.doi.org/10.4103/2229-516X.106352.

EKONG, MB., JOHN, EE., MBADUGHA, CC., BASSEY, EI. and EKANEM, TB. Effects of calabash chalk on the histomorphology of the gastro-oesophageal tract of growing Wistar rats. The Malaysian Journal of Medical Sciences, 2012, vol. 19, n. 1, p. 30-35.

EKONG, MB., PETER, AI., AKPANABIATU, M., EKANEM, TB. and ELUWA, MA. Potency of calabash chalk on the liver function and histomorphology. Journal of Medical Research and Practice, 2013, vol. 2 , n. 7 , p. 202-207.

FRUMKIN, H. and THUN, MJ. Arsenic. CA: a Cancer Journal for Clinicians, 2001, vol. 51, n. 4, p. 254-262. PMid:11577490. http:// dx.doi.org/10.3322/canjclin.51.4.254.

GOYER, RA. Results of lead research: prenatal exposure and neurological consequences. Environmental Health Perspectives, 1996, vol. 104, n. 10, p. 1050-1054. PMid:8930545. http://dx.doi.org/10.1289/ ehp.961041050.
HALSTED, JA. Geophagia in man: its nature and nutritional effects. The American Journal of Clinical Nutrition, 1968, vol. 21, n. 12, p. 1384-1393. PMid:4881679.

KHAN, OH., ENNO, TL. and DEL BIGIO, MR. Brain damage in neonatal rats following kaolin induction of hydrocephalus. Experimental Neurology, 2006, vol. 200, n. 2, p. 311-320. PMid:16624304. http:// dx.doi.org/10.1016/j.expneurol.2006.02.113.

MAPHERSON, RA. and PINCUS, MR. Henry's clinical diagnosis and management by laboratory methods. Philadelphia: WB Saunders, 2007. p. 25-28.

OLUWOLE, FS. and BOLARINWA, AF. Jatropacurcus extract causes anaemia in rats. Phytotherapy Research, 1998, vol. 11, p. 538-539.

POPOOLA, OE., BISI-JOHNSON, MA., ABIODUN, A. and IBEH, OS. Heavy metal content and antimicrobial activities of some naturally occurring facial cosmetics in Nigeria. Ife Journal of Science, 2013, vol. 15, n. 3, p. 637-645.

QURESHI, N., SHARMA, R., MOGRA, S. and PANWAR, K. Amelioration of lead induced alterations in ovary of Swiss mice, by antioxidant vitamins. Journal of Herbal Medicine and Toxicology, 2010, vol. 4, p. 89-95.

SHAH, AS., SHARIF, MM., KHAN, AS., TAYYAB, M., CHAUDARY, AN. and AHMED, N. Correlation of blood lead levels with atresia of ovarian follicles of albino mice. Annals of Pakistan Institute of Medical Sciences, 2008, vol. 4, p. 188-192.

SHANNON, M. Severe lead poisoning in pregnancy. Ambulatory Pediatrics: the Official Journal of the Ambulatory Pediatric Association, 2003, vol. 3, n. 1, p. 37-39. PMid:12540252.

SHARMA, R., QURESHI, N., MOGRA, S. and PANWAR, K. Lead induced infertility in Swiss mice and role of antioxidants. Universal Journal of Environmental Research and Technology, 2012, vol. 2, p. 72-82.

SILBERSTEIN, T., SAPHIER, O., PAZ-TAL, O., TRIMARCHI, JR., GONZALEZ, L. and KEEFE, DL. Lead concentrates in ovarian follicle compromises pregnancy. Journal of Trace Elements in Medicine and Biology, 2006, vol. 20, n. 3, p. 205-207. PMid:16959598. http:// dx.doi.org/10.1016/j.jtemb.2006.05.001.

TAUPEAU, C., POUPON, J., NOMÉ, F. and LEFÈVRE, B. Lead accumulation in the mouse ovary after treatment- induced follicular atresia. Reproductive Toxicology, 2001, vol. 15, n. 4, p. 385-391. PMid:11489594. http://dx.doi.org/10.1016/S0890-6238(01)00139-3.

YAO, P. A case of geophagia. Proceedings of UCLA Healthcare, 2006, vol. 10, p. 1-2.

Received March 7, 2017

Accepted August 7, 2017 